\title{
Severe Hyperprolactinemia Associated with Internal Carotid Artery Aneurysm: Differential Diagnosis between Prolactinoma and Hypothalamic-Pituitary Disconnection
}

\begin{abstract}
Sellar and parasellar masses blocking inhibitory hypothalamic dopaminergic tonus can produce hyperprolactinemia. One of these conditions, seldom reported, is internal carotid artery aneurysm causing pituitary stalk compression and hyperprolactinemia, the majority of which is related to small increases in serum prolactin levels. The aim of this study is to report the case of a patient with an internal carotid aneurysm and severe hiperprolactinemia. A 72 years old female patient, on oncology follow-up for clinically controlled cervical carcinoma, was evaluated due to worsening chronic headaches. During the investigation, computed tomography and magnetic resonance imaging (MRI) showed a sellar mass associated with high prolactin level $(1.403 \mu \mathrm{g} / \mathrm{L})$ that initially was considered a macroprolactinoma, and treated with bromocriptine. However, subsequent pituitary MRI suggested an internal carotid aneurysm, which was confirmed by an angioresonance imaging of cerebral vessels. On low bromocriptine dose (1.25 $\mathrm{mg} /$ day), there was a prompt normalization of prolactin levels with a great increase $(>600 \mu \mathrm{g} / \mathrm{L})$ after withdrawal, which was confirmed several times, suggesting HPD. We report a patient with internal carotid artery aneurysm with severe hyperprolactinemia never reported before in patients with HPD, and the need for a differential diagnosis with macroprolactinomas even considering high prolactin levels. (Arq Bras Endocrinol Metab 2008; 52/7:1189-1193)
\end{abstract}

Keywords: Hyperprolactinemia; Internal carotid artery aneurysm; Hypothalamicpituitary disconnection; Prolactinoma; Differential diagnosis of pituitary tumor

\section{RESUMO}

Hiperprolactinemia Severa Associada a Aneurisma Interno da Artéria Carótida: Diagnóstico Diferencial entre Prolactinoma e Desconexão Hipotálamohipofisária.

Massas selares e parasselares podem produzir hiperprolactinemia por bloquear o tônus inibitório hipotalâmico de dopamina. Uma destas condições, raramente reportada, é o aneurisma de artéria carótida interna causando compressão da haste hipofisária e hiperprolactinemia, a maioria com pequenas elevações da prolactina. O objetivo deste estudo é descrever o caso de uma paciente com aneurisma de carótida interna e grave hiperprolactinemia. Paciente feminina, 72 anos, em acompanhamento oncológico por carcinoma de colo de útero clinicamente controlado, avaliada por causa da piora de cefaléia crônica. Durante investigação, tomografia computadorizada e ressonância magnética (RM) de hipófise mostraram massa selar associada com altos níveis de prolactina $(1.403 \mu \mathrm{g} / \mathrm{L})$, sendo avaliado como macroprolactinoma e tratado com bromocriptina. Entretanto, RM subseqüente sugeriu aneurisma de carótida interna que foi confirmado por angiorressonância de vasos cerebrais. Em uso de baixas doses de bromocriptina $(1,25 \mathrm{mg} / \mathrm{dia})$, houve pronta normalização da prolactina com grande elevação (>600 $\mu \mathrm{g} / \mathrm{L}$ ) após a retirada do medicamento, sendo confirmado por várias vezes sugerindo $\mathrm{DHH}$. Reporta-se uma paciente com aneurisma de artéria carótida interna com grave hiperprolactinemia, nunca descrita anteriormente em pacientes com $\mathrm{DHH}$, e a necessidade do diagnóstico diferencial com macroprolactinoma, mesmo considerando altos níveis de prolactina. (Arq Bras Endocrinol Metab 2008; 52/7:1189-1193)

Descritores: Hiperprolactinemia; Aneurisma de artéria carótida interna; Desconexão hipotálamo-hipofisária; Prolactinoma; Diagnóstico diferencial de tumor hipofisário apresentação de caso

\author{
Felipe Henning Gaia Duarte \\ Marcio Carlos Machado \\ JOILMA RODRIGUES DE LIMA \\ LUIz Roberto Salgado
}

Endocrine Service, Hospital do Câncer A.C. Camargo, Fundação Antonio Prudente, (FHGD, MCM, JRL);

Neuroendocrine Unit, Division of Endocrinology and Metabolism, University of São Paulo School of Medicine (FHGD, MCM, LRS); São Paulo, SP, Brazil.

Recebido em 31/3/2008 Aceito em 22/7/2008 


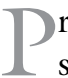
rolactin differs from other pituitary hormones as its secretion is regulated mainly through an inhibitory dopamine tonus, produced by neurons located in the hypothalamus (1). In addition to dopamine, other hypothalamic factors (TRH, oxytocin, VIP, angiotensin II, NPY and galanin) or even steroid hormones (estrogen) modulate the secretion of prolactin (2). The hypothalamic dopamine reaches the pituitary through the pituitary stalk and interacts with the dopamine receptor (D2), located in the cell membrane of lactotropes via protein Gi. After its binding, dopamine exerts an inhibitory effect on prolactin gene causing a reduction in secretion and hormone production (1).

Sellar and parasellar masses may hinder transportation of hypothalamic dopamine to the pituitary, leading to secondary hyperprolactinemia due to an absence of its inhibitory action on normal lactotropes (3). This process has been called hypothalamic-pituitary disconnection (HPD) and is classically associated to small or moderate serum prolactin increases, usually less than $100 \mu \mathrm{g} / \mathrm{L}$.

We report the case of a patient with sellar and suprasellar mass associated with a very high serum prolactin levels $(1.403 \mu \mathrm{g} / \mathrm{L})$ initially considered as a macroprolactinoma. This is an atypical case of severe hyperprolactinemia due to HPD, and it should be stressed that prolactin levels as high as in this case has never been reported before. The aim of this paper is to discuss the importance of the differential diagnosis between internal carotid aneurysm and macroprolactinoma.

\section{CASE REPORT}

A female patient, age 72 years, was evaluated in 1987 for cervical carcinoma and submitted to radiotherapy treatment with clinical remission. After three years, she presented worse chronic headaches, nausea and arterial hypertention. A cranial computed tomography (CT) revealed the presence of a sellar and suprasellar mass with a $20 \mathrm{~mm}$ diameter, which was confirmed by pituitary MRI. The patient had no complaints of decreased libido, abnormal visual fields or galactorrhea. Initial laboratory analysis excluded hematological, renal and hepatic abnormalities. Patient denied having taking medications that could lead to hyperprolactinemia. Hormonal assessment showed a prolactin level of $1403 \mu \mathrm{g} / \mathrm{L}(\mathrm{NV} 2-15 \mu \mathrm{g} / \mathrm{L})$ (Table 1) and panhypopituitarism (T4L $0.69 \mathrm{ng} / \mathrm{dL}, \mathrm{NV}: 1.0-1.8$ $\mathrm{ng} / \mathrm{dL}$; TSH $0.06 \mathrm{mUI} / \mathrm{L}, \mathrm{NV}: 0.3-4.2 \mathrm{mUI} / \mathrm{L}$; serum cortisol < $1.0 \mu \mathrm{g} / \mathrm{dL}, \mathrm{NV}: 5-25 \mu \mathrm{g} / \mathrm{dL}$; and IGFl 74 $\mu \mathrm{g} / \mathrm{L}, \mathrm{NV}:$ 96-502 $\mu \mathrm{g} / \mathrm{L})$. Screening for macroprolactinemia was negative as well. The patient was treated with replacement therapy of prednisone $5 \mathrm{mg} /$ day and thyroxine $100 \mu \mathrm{g} /$ day. As the high prolactin levels suggested a macroprolactinoma, she also received bromocriptine (BRC) starting with $1.25 \mathrm{mg} /$ day. A new pituitary MRI confirmed a sellar and suprasellar mass of similar dimensions of the previous one, but with heterogeneous content, which raised suspicion of a giant aneurysm of the internal carotid artery with a thrombus inside (Figure 1). This was confirmed by an angioresonance imaging of cerebral vessels (Figure 1). On BRC (1.25 mg/day), a dramatic reduction of prolactin levels was observed and the dosage was increased to $2.5 \mathrm{mg} /$ day when serum prolactin levels became almost undetectable $(0.6 \mu \mathrm{g} / \mathrm{L})$ (Table 1). After multi-disciplinary discussion, a conservative approach was chosen instead of surgery.

The patient continued BRC use for approximately one year when it was discontinued. Shortly after hyperprolactinemia as high as 657 and $437 \mu \mathrm{g} / \mathrm{L}$ was observed, bromocriptin was restarted with a dose of 2.5 $\mathrm{mg} /$ day with prolactin returning to normal values (Table 1). The drug was then gradually reduced to $0.625 \mathrm{mg} /$ day, keeping serum prolactin in normal range levels $(8.5 \mu \mathrm{g} / \mathrm{L})$. During imaging assessment, the aneurysm remained with the same diameter as in the initial exam, and the patient was kept in full replacement for hypopituitarism.

Table 1. Outcome of prolactin levels with bromocriptine use.

\begin{tabular}{lcc}
\hline Date & Bromocriptine $(\mathbf{m g} /$ day) & Prolactin $(\mathbf{\mu g} / \mathbf{L})$ \\
\hline September 2000 & Before & 1403.0 \\
\hline November 2000 & 1.25 & 38.0 \\
\hline January 2001 & 2.5 & 2.5 \\
\hline May 2001 & 2.5 & 0.6 \\
\hline September 2001 & Stop & 657.0 \\
\hline September 2001 & Stop & 437.0 \\
\hline October 2001 & 2.5 & 0.6 \\
\hline February 2003 & 1.25 & 6.0 \\
\hline July 2003 & 0.625 & 3.0 \\
\hline September 2004 & 0.625 & 1.0 \\
\hline November 2004 & Stop & 449.0 \\
\hline August 2005 & 0.625 & 2.3 \\
\hline January 2006 & 0.625 & 5.1 \\
\hline March 2006 & Stop & 405.0 \\
\hline June 2006 & Stop & 280.0 \\
\hline July 2006 & 0.625 & 8.5 \\
\hline
\end{tabular}




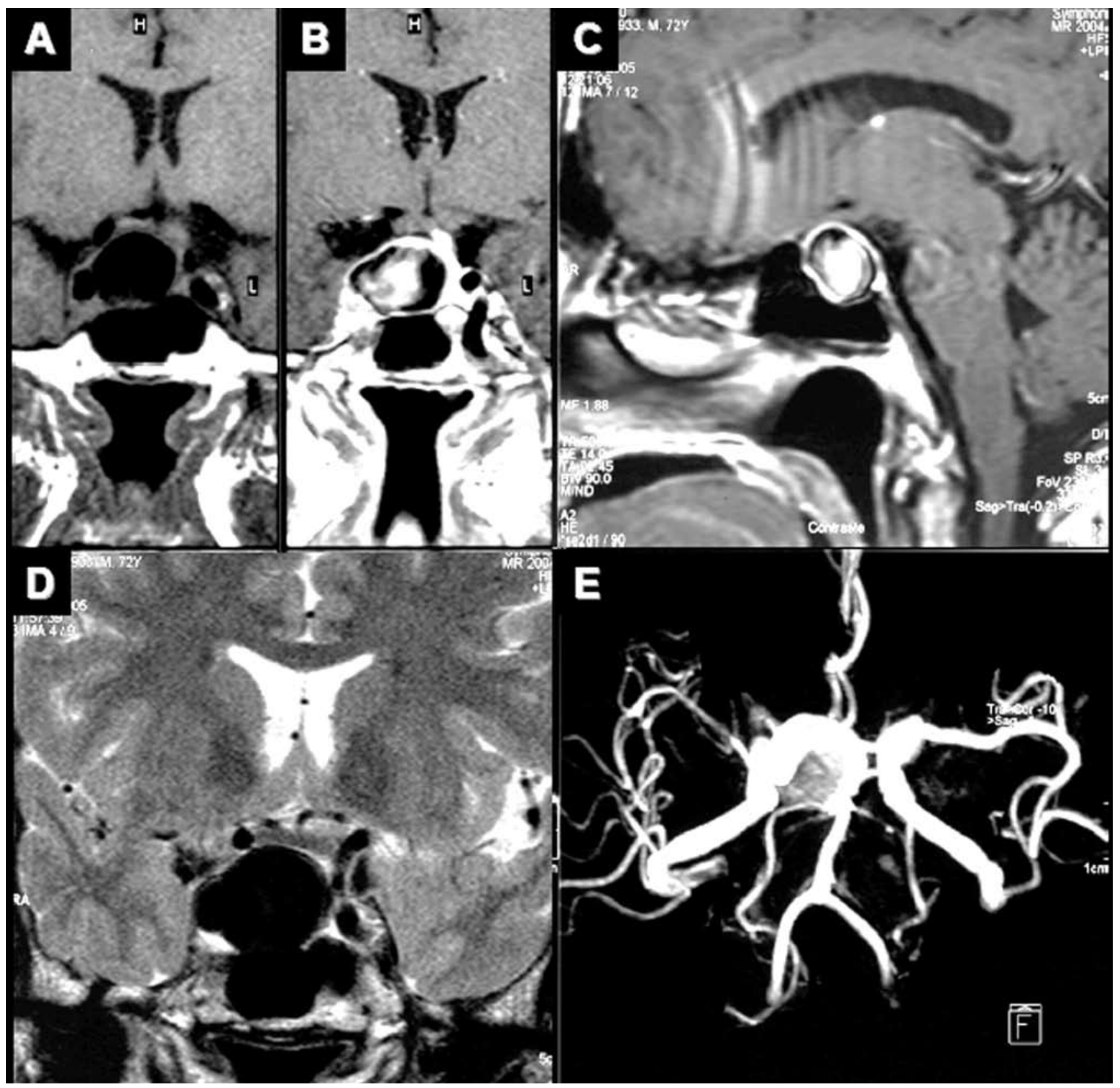

Figure 1. MRI and angioresonance of a 72 years old woman with internal carotid artery aneurysm. A: Coronal T1-weighed pituitary magnetic resonance imaging (MRI) without contrast (gadolinium), showing mass in sellar region located mainly on the right side of the sella turcica, hypointense, with small area of intermediate intensity in its interior, extending in the suprasellar direction, $20 \mathrm{~mm}$ in diameter; B: Coronal T1-weighed MRI after gadolinium, showing mass with heterogeneous content that had enhanced peripheral contrast, left deviation of pituitary stalk and probably pituitary parenchyma also diverting to the left; C: Sagital T1-weighed MRI post contrast, showing pituitary mass with heterogeneous content, suspect of internal carotid artery aneurysm with thrombus in its interior; D: Coronal T2-weighed MRI, showing the absence of liquid content in the sellar and suprasellar lesion; E. Angioresonance of cerebral vessels confirming gigantic aneurysm of right internal carotid artery. 
The Research Projects and Graduate Studies Commission and the Ethics Commission of our institutions approved the study, and the patient provided informed consent.

\section{Hormonal assay}

Serum prolactin was measured by commercial immunoassay (Bayer Advia Centaur, Indiana, USA).

\section{DISCUSSION}

The differential diagnosis of hyperprolactinemia includes a large number of clinical physiological situations (pregnancy, lactation, stress, sleep, exercise, maxillary stimulation) or pathological conditions (1). Among the pathological causes, the two most common etiologies are prolactinomas and use of anti-dopamine drugs. Other pathologic conditions such as polycystic ovary syndrome, hypothyroidism, adrenal failure, hepatic cirrhosis, chronic kidney failure, brain trauma injuries and clinically non-functioning pituitary adenomas are known causes of hyperprolactinemia (3). Furthermore, other lesions of the hypothalamic-pituitary region also can cause increased secretion of prolactin due to HPD. In addition to HPD, the rise in intrasellar pressure caused by pituitary masses can also lead to increased levels of serum prolactin (4). However, both increases of intrasellar pressure and suprasellar masses causing HPD are usually associated with moderated increases of serum prolactin levels (4-6).

Classically, serum levels of prolactin higher than $200 \mu \mathrm{g} / \mathrm{L}$ are related to macroprolactinomas, but those levels should not exclude other etiologies or even use of anti-dopamine drugs as been reported in literature (7). Therefore, any sellar masses among craniopharyngiomas, optical gliomas, secondary metastatic implants, chordomas and internal carotid aneurysms can be associated with moderated increases of serum prolactin levels and should be differentiated from prolactinomas $(8,9)$.

It should be mentioned that co-existence of aneurysm of internal carotid and hyperprolactinemia is usually iatrogenic (10), and descriptions of its primary association is rare (11). Another considered possibility was the presence of a co-existing prolactinoma. Although rare, few reports described this association (12-15), however in all cases the macroadenoma was evident in the images obtained, a situation that was ruled out in our case. The first published case of internal carotid aneurysm and primary hyperprolactinemia was reported by Verbalis et al.(5), in 1982, in a 59 years old patient with hypopituitarism and prolactin serum levels of $177 \mu \mathrm{g} / \mathrm{L}$ related to internal carotid aneurysm. After the aneurism surgical decompression serum prolactin levels returned to normal. Thereafter, a number of new cases were reported over the subsequent years $(6,8,9,15-21)$.

An important clinical aspect of these reported cases is the female prevalence and age ranged between 42 and 76 years, exceptions being a case reported by Kayath et al. (18-year-old male patient) and two other patients reported by Fonseca et al.(17), both males, age 57 and 68 years. Serum prolactin levels ranged between 4 and $182 \mu \mathrm{g} / \mathrm{L}(5,6,8,9,16,17,19-21)$ associated with hypopituitarism. Clinically, the most common complaints were headaches and blurred vision attributed to the mass effect.

In only two reported cases, serum prolactin levels were higher than $200 \mu \mathrm{g} / \mathrm{L}$. The first was reported by Fernandez-Real et al.(18), who described a case of a 52 -year-old women with a giant aneurysm associated with subarachnoid hemorrhage and serum prolactin levels of $1.093 \mu \mathrm{g} / \mathrm{L}$ who presented sudden headaches, a decline in consciousness, hemiparesis and signs, and symptoms relate to hypopituitarism. In the second case, published by Kahn et al.(15), a 42 years old patient presented galactorrhea, headaches, abnormal visual fields and serum prolactin levels of $365 \mu \mathrm{g} / \mathrm{L}$.

In the case reported, the patient presented higher serum prolactin levels, associated with internal carotid aneurysm $(1.403 \mu \mathrm{g} / \mathrm{L})$, than reported in the literature to date. Our case was noticed to be similar to that case reported by Kahn et al. (15) where there were no other factors besides the internal carotid aneurysm that could cause compression leading to HPD and hyperprolactinemia. It should be stressed that there is no histological proof excluding a macroprolactinoma extremely sensitive to dopamine agonist. However, the absence of imaging suggestive of pituitary adenoma, an angioresonance confirming a giant aneurysm of internal carotid artery and the extreme sensibility to the BRC presented by the patient, strongly suggest hyperprolactinemia secondary to the HPD.

In conclusion, we reported a case of a patient with severe hyperprolactinemia due to HPD caused by internal carotid artery aneurysm, stressing the need for a more critical evaluation in the differential diagnosis, when con- 
sidering the presence of sellar masses. A test with low dose of dopamine agonist, independent of serum prolactin levels, could be a clue to the diagnosis of HPD.

\section{REFERENCES}

1. Ben-Jonathan N, Hnasko R. Dopamine as a prolactin (PRL) inhibitor. Endocr Rev. 2001;22:724-63.

2. Freeman ME, Kanyicska B, Lerant A, Nagy G. Prolactin: structure, function, and regulation of secretion. Physiol Rev. 2000;80:1523-31.

3. Melmed S, Kleinberg D. Anterior pituitary. In: Larsen PR, Kronenberg HM, Melmed S, Polonsky KS, editores. Willians textbook of endocrinology. 10a ed. Philadelphia: Saunders; 2002. p. 205-7.

4. Arafah BM, Prunty D, Ybarra J, Hlavin ML, Selman WR. The dominant role of increased intrasellar pressure in the pathogenesis of hypopituitarism, hyperprolactinemia, and headaches in patients with pituitary adenomas. J Clin Endocrinol Metab. 2000;85:1789-93.

5. Verbalis JG, Nelson PB, Robinson AG. Reversible panhypopituitarism caused by a suprasellar aneurysm: the contribution of mass effect to pituitary dysfunction. Neurosurgery. 1982;10:604-11.

6. Borges FZ, Ferreira BP, Resende EA, Neto EN, Borges WA, Oliveira RS, Borges MF. Aneurisma gigante de carótida interna simulando macroadenoma de hipófise. Arq Bras Endocrinol Metab. 2006;50:558-63.

7. Kleinberg DL, Gordon LN, Frantz AG. Galactorrhea: a study of 235 case, including 48 pituitary tumors. N Engl J Med. 1977;296:589-600.

8. Kayath MJ, Lengyel AM, Nogueira R, Tella Junior O, Czepielewski MA. Giant aneurysms of the sellar region simulating pituitary adenomas: a diagnosis to be considered. J Endocrinol Invest. 1991;14:975-9.

9. Arlot S, Lalau JD, Galibert P, Quichaud J. Intrasellar carotid aneurysm simulating prolactin adenoma. Rev Med Interne. 1985;6:505-9.

10. Reddy K, Lesiuk H, West M, Fewer D. False aneurysm of the cavernous carotid artery: a complication of transsphenoidal surgery. Surg Neurol. 1990;33:142-5.

11. Wakai S, Fukushima T, Furihata T, Sano K. Association of cerebral aneurysm with pituitary adenoma. Surg Neurol. 1979;12: 503-7.
12. Yang MY, Chen $C$, Shen CC. Cavernous aneurysm and pituitary adenoma: management of dual intrasellar lesions. J Clin Neurosci. 2005:12:477-81.

13. Chuang $C C$, Chen $Y L$, Pai PC. A giant intracavernous carotid artery aneurysm embedded in pituitary macroadenoma presenting with pituitary apoplexy. Cerebrovasc Dis. 2006;21:142-4.

14. Sony A, de Silva SR, Allen K, Byrne JV, Cudlip S, Wass JA. A case of macroprolactinoma encasing an internal carotid aneurysm, presenting as pituitary apoplexy. Pituitary. 2007 [Epub ahead of print].

15. Kahn SR, Leblanc R, Sadikot AF, Fantus IG. Marked hyperprolactinemia caused by carotid aneurysm. Can J Neurol Sci. 1997;24:64-6.

16. Romano A, Chibbaro S, Marsella M, Ippolito S, Benericetti E. Carotid cavernous aneurysm presenting as pituitary apoplexy. J Clin Neurosci. 2006;13:476-9.

17. Fonseca $A L$, Souto $A A$, Domingues $F$, Vaisman $M$, Gadelha MR, Chimelli L, et al. Hormonal dysfunction of nonpituitary lesions from midline and perisellar área. Arq Neuropsiquiatr. 2001;59:905-12.

18. Fernandez-Real JM, Fernandez-Castaner M, Villabona C, Sagarra E, Gomez-Saez JM, Soler J. Giant intrasellar aneurysm presenting with panhypopituitarism and subarachnoid hemorrhage: case report and literature review. Clin Investig. 1994;72:302-6.

19. Mindel JS, Sachdev VP, Kline LB, Sivak MA, Bergman DA Yang WC, et al. Bilateral intracavernous carotid aneurysms mimicking a prolactin-secreting pituitary tumor. Surg Neurol. 1983;19:163-7

20. Ooi TC, Russell NA. Hypopituitarism resulting from an intrasellar carotid aneurysm. Can J Neurol Sci. 1986;13:70-1.

21. Michils A, Baleriaux D, Mockel J. Bilateral carotid aneurysm unmasked by severe hypopituitarism. Postgrad Med J. $1991 ; 67: 285-8$

Correspondence to:

Luiz Roberto Salgado

Av. Dr. Eneas de Carvalho Aguiar \#155, $8^{\text {th }}$ floor, Cerqueira Cesar University of São Paulo School of Medicine

05403-060 São Paulo, SP - Brazil

E-mail: salga@uol.com.br 